\title{
Holocene paleohydrological reconstruction of Lake Strzeszyńskie (western Poland) and its implications for the central European climatic transition zone
}

\author{
Krzysztof Pleskot D $\cdot$ Rik Tjallingii • Mirosław Makohonienko • \\ Norbert Nowaczyk $\cdot$ Witold Szczuciński
}

Received: 9 February 2017/ Accepted: 23 September 2017/Published online: 5 October 2017

(C) The Author(s) 2017. This article is an open access publication

\begin{abstract}
Western Poland is located in the central European climatic transition zone, which separates the mild and humid Atlantic climate of Western Europe and the East European continental climate. This region is sensitive to lateral shifts of the European climate zones and is particularly suitable for reconstructing Holocene climate variability. This paper presents detailed analyses of the sedimentary record from Lake Strzeszyńskie since the Late Pleistocene. These include smear-slide and thin-section observations, X-ray fluorescence core scanning, magnetic susceptibility measurements, pollen analyses, and radiocarbon dating. The sediment record reveals three distinct sedimentary units consisting of: (1) an alternation of sand layers and laminated silt and clay deposits accumulated prior to $14,600 \mathrm{cal} \mathrm{yr} \mathrm{BP;}$ (2) faintly laminated calcareous sediments intercalated
\end{abstract}

K. Pleskot $(\bowtie) \cdot$ W. Szczuciński

Institute of Geology, Adam Mickiewicz University in

Poznan, Bogumiła Krygowskiego 12, 61-680 Poznan,

Poland

e-mail: krzypl@amu.edu.pl

W. Szczuciński

e-mail: witek@amu.edu.pl

R. Tjallingii · N. Nowaczyk

Section 5.2 Climate Dynamics and Landscape Evolution,

GFZ German Research Centre for Geosciences,

Telegrafenberg, 14473 Potsdam, Germany

e-mail: tjalling@gfz-potsdam.de

N. Nowaczyk

e-mail: nowa@gfz-potsdam.de with organic matter-rich layers deposited between 14,600 and 10,200 cal yr BP; and (3) massive calcareous mud deposited after 10,200 cal yr BP. The Holocene period is marked by nine phases of organicrich sedimentation and enhanced $\mathrm{Fe}$ deposition, which occurred at ca. 10.1, 9.3, 6.4-6.1, 5.5-5.1, 4.7-4.5, 2.7-2.4, 1.3-1.2, 0.8-0.6, 0.4-0.2 kyr cal BP. These phases are associated with high lake levels and correspond with wet periods recognized in several other records from Poland and central Europe. These phases partly coincide with North Atlantic cold periods, which may suggest that high lake levels are triggered by an ocean-continent linking mechanism.

Keywords Lacustrine sediments - Lake level changes $\cdot$ XRF scanning $\cdot$ Central Europe

\footnotetext{
K. Pleskot - M. Makohonienko

Institute of Geoecology and Geoinformation, Adam

Mickiewicz University in Poznan, Bogumiła

Krygowskiego 10, 61-680 Poznan, Poland

e-mail: makoho@amu.edu.pl

K. Pleskot

Laboratory of Wetland Ecology and Monitoring, Adam

Mickiewicz University in Poznan, Bogumiła

Krygowskiego 10, 61-680 Poznan, Poland
} 


\section{Introduction}

The central European transitional climate zone migrated over central Europe on decadal to millennial time-scales, mostly due to external forcing mechanisms (Ljungqvist et al. 2016). However, the complex reconstruction teleconnections amongst the cryosphere, ocean and atmosphere are often biased by more-local influences in terrestrial records (Magny 2004). Therefore, a robust reconstruction of the Holocene climate variations over the European continent requires a good geographical coverage of welldated paleoclimatic records.

Poland might be particularly sensitive to such shifts of the European climate zones due to its position between the western and eastern European climate zones (Lamentowicz et al. 2015). Several records have documented variations in the effective precipitation in Poland associated with the migration of the central European transition zone (Gałka et al. 2013, 2015; Lamentowicz et al. 2015; Słowiński et al. 2016; Apolinarska and Gałka 2017). Twelve distinct wet periods lasting from one hundred up to one thousand years have been identified over Poland during the Holocene (Starkel et al. 2013). However, current regional paleoclimatic reconstructions of Poland suffer from the relatively poor spatial coverage of detailed and well-dated records.

The extensive distribution of postglacial lakes that cover the Weichselian moraine landscape of the central European lowlands provides a good potential for additional Holocene climatic records. Lake records have been used, for instance, to reconstruct Late Quaternary lake-level variations and associated changes in effective precipitation (Magny 2004). Changes in water volume often reflect ecological, physical and chemical processes that control the rate of calcite carbonate precipitation and dissolution, which can effectively be traced in the sedimentary record (Haberzettl et al. 2005; Pompeani et al. 2012; Ohlendorf et al. 2013; Dietze et al. 2016).

This paleolimnological study presents the postglacial sediment record from Lake Strzeszyńskie. Changes in the sediment composition of this welldated record provide first indications of nine episodes associated with elevated lake levels and effective precipitation during the Holocene.
Regional setting

Lake Strzeszyńskie is located in the eastern part of the Poznań Lake District of western Poland (Fig. 1). The NW-SE elongated lake basin is part of a glacial tunnel valley (Fig. 1d). It was formed during recession of the Weichselian ice sheet, which retreated from the area around $18.5 \mathrm{ka}$ BP (Kozarski 1995). The surface sediments of the relatively small catchment $\left(8.1 \mathrm{~km}^{2}\right)$ consist of glacial till and glaciofluvial sand and gravel deposits (Fig. 1e). Holocene peats are found locally in the catchment area and outcrops of Neogene clay and silt deposits are found in glaciotectonically deformed moraines of the Morasko hill (Karczewski 1976; Stankowski 2008).

Lake Strzeszyńskie covers an area of $0.349 \mathrm{~km}^{2}$ and consists of two main depressions with a maximum depth of $17.8 \mathrm{~m}$ (Fig. 1c). Two small and intermittent streams enter the lake at the North, and two outflows are located at the South of the lake. Insignificant surficial inflows suggest that groundwater is the primary source of recharge to the lake. The mean annual precipitation of $528 \mathrm{~mm}$ is relatively low and has varied from 321 to $764 \mathrm{~mm}$ over the last few decades (Woś 1994). Precipitation is highest in July and lowest in February. The mean temperatures are below zero between December and early March. Lake Strzeszyńskie is dimictic and became eutrophic in recent years due to increased nutrient supply by enhanced anthropogenic activities (Szeląg-Wasielewska 2004).

\section{Materials and Methods}

Sediment core Strze3a was recovered close to the deepest part of the lake in 2015 (Fig. 1c) using a 60-mm-diameter UWITEC piston corer. All the core segments were split lengthwise, were visually described according to Schnurrenberger et al. (2003) and were photographed directly after opening.

Magnetic susceptibility was measured every $2 \mathrm{~mm}$ directly at the split core surface using an automatic logger equipped with a Bartington MS2E device (Nowaczyk 2002). The elemental composition was measured every $2 \mathrm{~mm}$ non-destructively using an ITRAX XRF core scanner (Croudace et al. 2006). XRF scanning was performed with a $\mathrm{Cr} \mathrm{X}$-Ray source $(30 \mathrm{kV} / 30 \mathrm{~mA})$ and an exposure time of $10 \mathrm{~s}$. The 


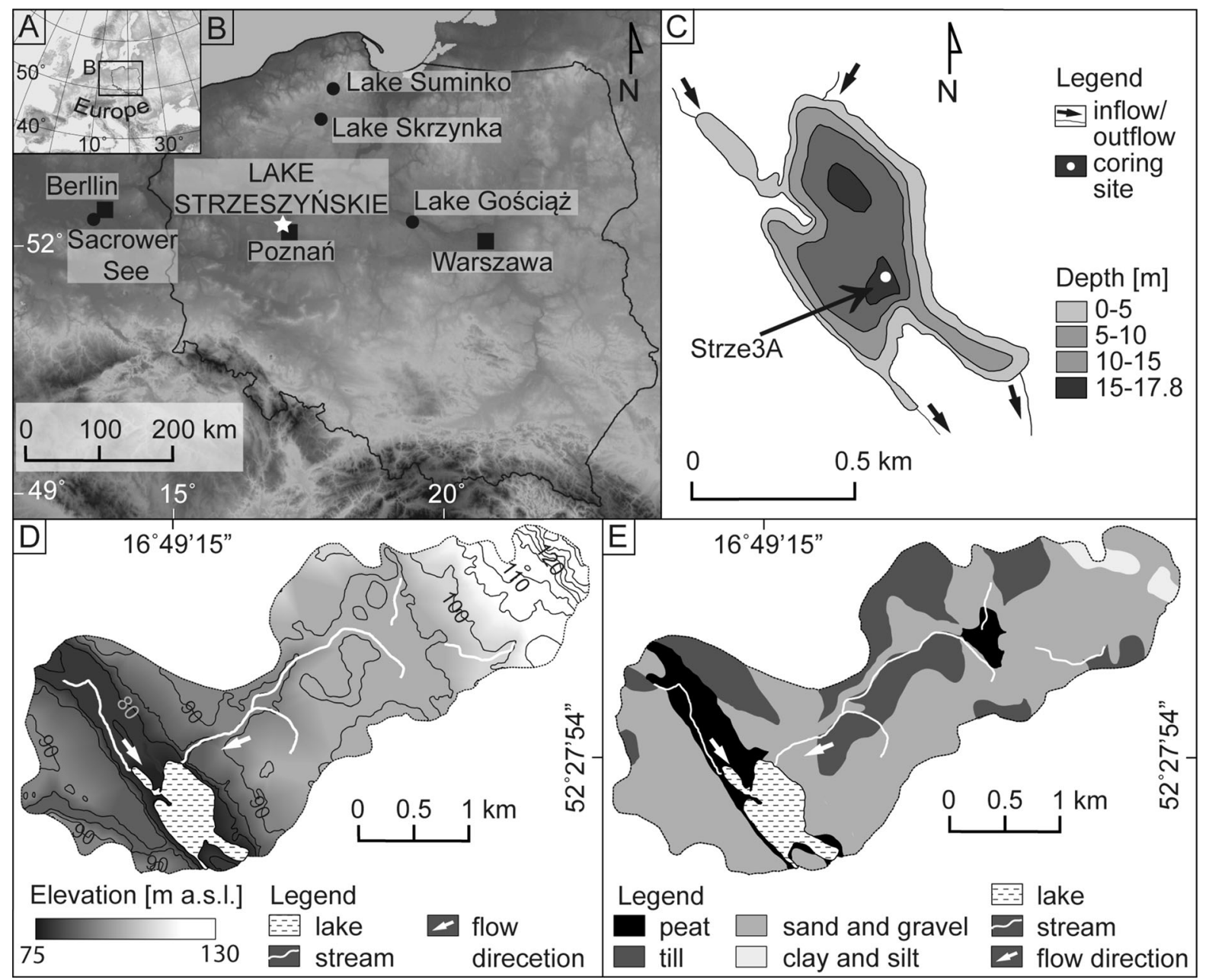

Fig. 1 Map of Lake Strzeszyńskie and drainage region. a Location of the region of interest within Europe. b Map of Poland with marked study site: Lake Strzeszyńskie as well as sites with well-studied lake records from the region discussed in

analytical precision was obtained from replicate measurements that were obtained at three intervals of $\sim 2 \mathrm{~cm}$ for the most-prominent lithologies in each of the sediment segments. The ITRAX XRF scanner provides element intensities that are calculated by peak integration of the measured XRF-spectra after background subtraction and deconvolution. The obtained element intensities are non-linear functions of element concentrations predominantly due to matrix absorption and enhancement effects (Weltje and Tjallingii 2008). Therefore high-resolution XRF scanning records are presented as log-ratios of element intensities as these are a linear functions of log-ratios of concentrations and allow the application of the text. c Bathymetry of Lake Strzeszyńskie and coring site of the Strze3a sediment core. d, e respectively present a simplified morphology and surficial geology of the Lake Strzeszyńskie catchment

meaningful multivariate statics (Weltje et al. 2015). Compositional changes are explored using biplots of the log-transformed XRF data that visualize the loadings (variables) and scores (data points) of the principal component analyses (PCA). The length of the loadings reveals the relative strength of the variables, and the orientation indicates the correlation of the elements. Positively correlated elements will have a similar orientation in the biplot, whereas negatively correlated elements are located opposite each other. Samples for thin sections $(100 \times 15 \times 35 \mathrm{~mm})$ were obtained at depths between 510 and $410 \mathrm{~cm}$ and between 210 and $300 \mathrm{~cm}$. These samples were prepared after Brauer 
and Casanova (2001) and used for micro-facies analyses under a microscope. Smear slides were prepared for the remaining parts of the core and were analysed under a microscope.

Samples for pollen were analysed every $15-50 \mathrm{~cm}$ using $\sim 1 \mathrm{~cm}^{3}$ bulk sediment. The samples were processed according to the standard method described by Berglund and Ralska-Jasiewiczowa (1986). Pollen percentages were preferably calculated on $>500$ counts of pollen grains, except for core segment 51, where the pollen concretions are too low. Telmatophytes and limnophytes were excluded for normalization of arboreal pollen (AP) and non-arboreal pollen (NAP). Pollen spectra were analysed as a support to the age model and to indicate the main stages of vegetation cover development in the lake catchment.

Altogether, 30 radiocarbon ages were obtained from the bulk sediment samples and analysed by the Poznan Radiocarbon Laboratory (Table 1). There are very few macrofossils in the core, so the analyses focused on bulk sediments. To assess effects of older carbon 6 samples were extracted following Brock et al. (2010) to determine the 'residual' (alkali-insoluble or "humin") and 'soluble' (alkali-soluble or "humic") fractions. Separation of the residual and soluble fractions can help to distinguish between terrestrial and aquatic or bacterial sources (Meyers and Ishiwatari 1993). The radiocarbon chronology was constructed using the ${ }^{14} \mathrm{C}$ AMS results of 16 bulk sediment samples and 6 residual fractions in combination with 2 biostratigraphical markers. The radiocarbon results were converted into calendar years using the IntCal13 calibration curve (Reimer et al. 2013) with $2 \sigma$ precision. Construction of an age-depth model was performed with the Bacon software (Blaauw and Christen 2011) and with linear interpolation between the stratigraphic age points and between the stratigraphic age point and the oldest ${ }^{14} \mathrm{C}$ date used in model. The Bacon software performs Bayesian age-depth modelling that includes the dating probability distribution and excludes negative sediment accumulation rates.

\section{Results}

\section{Sediment chronology}

Most of the obtained ${ }^{14} \mathrm{C}$ ages continuously increase with depth (Table 1). For 7 bulk sediment samples, the calibrated ages are out of chronological order. The minimum age reversals are between 40 and 200 years, except for a sample from the 642.1-642.6 cm depth that is at least 2000 years older than the sample taken below.

For 6 samples, the age is assessed for soluble and residual carbon fractions, which reveal that the age relationship between the fractions is not straightforward (Table 1). Compared with the residual carbon fraction, the soluble fraction appears to be exactly the same age, a similar age, slightly younger or slightly older. The 2-sigma calibrated age ranges of the same sample in various fractions overlap in 3 cases. For the remaining 3 samples, the calibrated 2-sigma ranges differ by at least 40-250 years, and in case of two samples, the older age is in soluble fraction.

The age model (Fig. 2) of the Strze3a composite record was constructed using 22 radiocarbon samples and the two stratigraphic age points related to beginning and termination of Younger Dryas. These points were acquired based on the lithology, geochemical composition and biostratigraphy. The Bacon-based analysis combined with linear interpolation (applied to the core interval extended beyond the range of the oldest ${ }^{14} \mathrm{C}$ sample used in the model and to the stratigraphic gap between the 665 and $700 \mathrm{~cm}$ depth) reveal sediment accumulation rates ranging between 0.2 and $1.1 \mathrm{~mm} \mathrm{yr}^{-1}$. The highest values were noted during the early Holocene and the lowest during the middle Holocene.

\section{Lithology and stratigraphy}

The composite sediment record was constructed from the two parallel cores based on visual correlation of overlapping segments in combination with the magnetic susceptibility and $\mathrm{Ca} / \mathrm{Fe} \mathrm{XRF}$ records (Fig. 3). The total composite record is $850 \mathrm{~cm}$ long, including a gap indicated between 665 and $700 \mathrm{~cm}$, as there is no recovery for this part of the core. The main lithological units were defined based on visual core description and smear slide observations in combination with magnetic susceptibility and XRF-scanning data (Fig. 3).

Lithological Unit-I $(850-731 \mathrm{~cm})$ is mainly composed of sand layers alternated by laminated silt and clay deposits. The base of Unit-I consists of medium to coarse sand (Fig. 3) followed by a 30-cm-thick laminated silt and clay deposit and a fine sand layer that is $\sim 25 \mathrm{~cm}$ thick. Laminated silt and clay 
Table 1 AMS ${ }^{14} \mathrm{C}$ dates and calibrated dates of bulk sediments as well as soluble and residual carbon fractions separated from bulk sediment samples

\begin{tabular}{|c|c|c|c|c|c|}
\hline Depth $(\mathrm{cm})$ & Dated material & Lab. no. & AMS ${ }^{14} \mathrm{C}(\mathrm{yr} \mathrm{BP})$ & Cal yr BP (2-sigma range) & Date used in depth model \\
\hline $85.5-86$ & Bulk sediment & Poz-76680 & $1260 \pm 30$ & $1172-1281$ & Yes \\
\hline $121.5-122$ & Bulk sediment & Poz-76681 & $2335 \pm 30$ & $2311-2438$ & Yes \\
\hline $140.5-141$ & Bulk sediment & Poz-76682 & $2550 \pm 35$ & $2683-2752$ & Yes \\
\hline $183.6-184.1$ & Bulk sediment & Poz-76684 & $3285 \pm 35$ & $3445-3592$ & Yes \\
\hline $206-206.5$ & Bulk sediment & Poz-76685 & $4000 \pm 35$ & $4411-4534$ & Yes \\
\hline $257.5-258$ & Bulk sediment & Poz-74576 & $5070 \pm 50$ & $5710-5919$ & Yes \\
\hline $266-266.5$ & Soluble fraction & Poz-77129 & $4890 \pm 35$ & $5585-5664$ & No \\
\hline $266-266.5$ & Residual fraction & Poz-77321 & $4890 \pm 35$ & $5585-5664$ & Yes \\
\hline $267-267.5$ & Soluble fraction & Poz-77125 & $4950 \pm 40$ & $5597-5748$ & No \\
\hline $267-267.5$ & Residual fraction & Poz-77126 & $5330 \pm 35$ & $5996-6209$ & Yes \\
\hline $268-268.5$ & Soluble fraction & Poz-77124 & $5040 \pm 40$ & $5708-5902$ & No \\
\hline $268-268.5$ & Residual fraction & Poz-77123 & $5095 \pm 35$ & $5747-5833$ & Yes \\
\hline $268.5-269$ & Soluble fraction & Poz-74747 & $4970 \pm 30$ & $5610-5747$ & No \\
\hline $268.5-269$ & Residual fraction & Poz-74745 & $4705 \pm 35$ & $5321-5421$ & Yes \\
\hline $269-269.5$ & Soluble fraction & Poz-77128 & $5130 \pm 40$ & $5844-5944$ & No \\
\hline $269-269.5$ & Residual fraction & Poz-77740 & $5265 \pm 35$ & 5934-6124 & Yes \\
\hline $276-276.5$ & Bulk sediment & Poz-74577 & $5505 \pm 35$ & $6272-6357$ & Yes \\
\hline $284-284.5$ & Soluble fraction & Poz-77132 & $5730 \pm 40$ & $6435-6637$ & No \\
\hline $284-284.5$ & Residual fraction & Poz-77130 & $5540 \pm 40$ & $6285-6404$ & Yes \\
\hline $387.7-388.2$ & Bulk sediment & Poz-71021 & $7600 \pm 50$ & $8334-8483$ & Yes \\
\hline $433-433.6$ & Bulk sediment & Poz-71023 & $8280 \pm 50$ & $9121-9436$ & Yes \\
\hline $435.95-436.45$ & Bulk sediment & Poz-71024 & $8280 \pm 50$ & 9121-9436 & Yes \\
\hline $436.45-436.95$ & Bulk sediment & Poz-71025 & $8210 \pm 50$ & 9019-9307 & Yes \\
\hline $436.95-437.45$ & Bulk sediment & Poz-71026 & $8220 \pm 50$ & $9025-9310$ & Yes \\
\hline $437.45-437.95$ & Bulk sediment & Poz-71027 & $8330 \pm 50$ & $9236-9472$ & Yes \\
\hline $437.95-438.45$ & Bulk sediment & Poz-71028 & $8220 \pm 50$ & $9025-9310$ & Yes \\
\hline $447-447.5$ & Bulk sediment & Poz-71029 & $8290 \pm 50$ & $9128-9437$ & Yes \\
\hline $491.7-492.2$ & Bulk sediment & Poz-71065 & $8920 \pm 50$ & $9890-10,218$ & Yes \\
\hline $642.1-642.6$ & Bulk sediment & Poz-77052 & $15,430 \pm 90$ & $18,505-18,879$ & No \\
\hline $712.5-713$ & Bulk sediment & Poz-71066 & $13,560 \pm 70$ & $16,103-16,606$ & No \\
\hline
\end{tabular}

The samples used for the age model are marked. The selection of dates for the age model is discussed in the text

deposits are found continuously between the $789 \mathrm{~cm}$ depth and the boundary of Unit-I and Unit-II.

Unit-II $(731-510 \mathrm{~cm})$ consists of faintly laminated sediments that are intercalated with organicrich layers and show the presence of iron-sulfide minerals. The base of Unit-II is marked by a massive brown organic-rich layer that is $\sim 15 \mathrm{~cm}$ thick and that marks the boundary between Unit-I and Unit-II. The smear slide observations of this layer show high amounts of amorphous organic matter, with only very few terrestrial-plant remains and siliceous microfossils. Detrital material of this layer consists predominately of quartz grains, with minor contributions of detritic carbonates, grains of epidote, limonite and zircon. Faintly laminated mud with relatively high amounts of authigenic carbonates, algae remains and diatoms are found above the brown organic-rich layer. Another organic rich layer is found above the gap between 665 and $654 \mathrm{~cm}$. This layer consists of brownish sediments with amorphous organic matter and a moderate contribution of authigenic carbonates, diatoms, chrysophytes and clastic grains. A thin $(\sim 0.5 \mathrm{~cm})$ coarse-silt layer marks the boundary between the organic-rich 


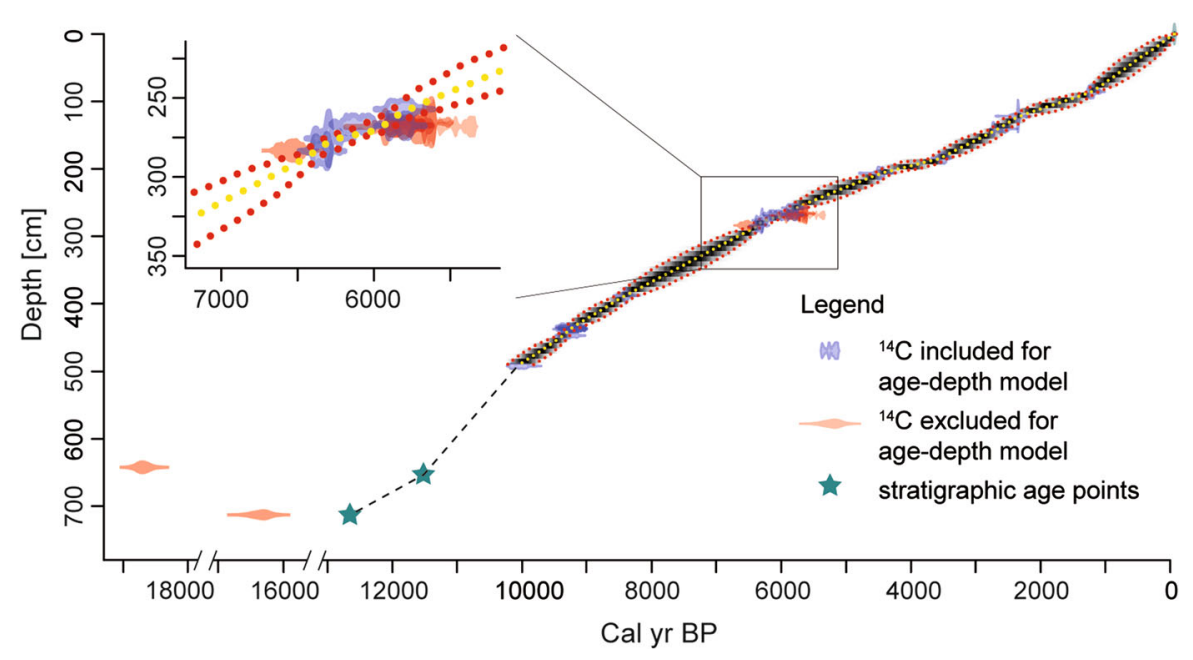

Fig. 2 Age-depth model for the investigated sediment core. Calibrated AMS ${ }^{14} \mathrm{C}$ dates are shown in transparent blue except of dates excluded for age-depth model which are shown in transparent red. Bacon-based model spanning the last ca. $10.1 \mathrm{kyr}$ cal BP. Darker greys indicate more likely calendar ages. Red stippled lines show $95 \%$ confidence intervals. Yellow curve shows single 'best' model based on the weight mean age for each depth. Due to the lack of reliable ${ }^{14} \mathrm{C}$ dates in the lower

layer and faintly laminated calcareous muds deposited between 654 and $588 \mathrm{~cm}$ depth. These sediments contain relatively low amounts of diatoms and a gradually decreasing organic content. The laminations terminate at approximately $588 \mathrm{~cm}$ depth, and the sediments become homogeneous. The boundary between Unit-II and Unit-III is clearly marked in the magnetic susceptibility XRF-scanning records (Fig. 2) but is poorly constrained by visual observations.

Unit-III $(510-0 \mathrm{~cm})$ is mainly composed of massive, gray calcareous mud with low to moderate amounts of chrysophytes, diatoms and iron-sulphide minerals. These homogeneous sediments are alternated by dark gray and often faintly laminated layers that are several $\mathrm{cm}$ thick (at 494, 445, 436, 275, 236, $211,140,131,86,55$ and $25 \mathrm{~cm}$ ). Thin section observations reveal that the light laminae of these layers contain higher amounts of calcareous material, whereas darker laminae are mainly composed of chrysophytes, diatoms, iron-sulphides minerals and amorphous organic matter. A thicker layer of light gray and homogenous calcareous mud is found at a 100-123 cm depth, with mainly authigenic carbonates and chrysophytes. part, the chronology of the core is based on distinct bio-, lithoand geochemical boundaries that are assumed to represent the onset and termination of the Younger Dryas period. Beyond the range of reliable ${ }^{14} \mathrm{C}$ samples model is based on linear interpolation traced by black dotted line. Chronological uncertainties, though not quantified, are considered significant within this part. (Colour figure online)

\section{Core scanning}

Non-destructive magnetic susceptibility and XRF core scanning were obtained by relative magnetic properties and compositional variations of core Strze3a. The magnetic susceptibility values are high for the siliciclastic sediments of Unit-I (Fig. 3). The scarcity of siliciclastic sediments and the abundance of ironsulphides in Unit-II and Unit-III suggest that lake oxygenation and diagenetic Fe reduction control the magnetic susceptibility record in this part of the core. The generally undifferentiated magnetic susceptibility record of Unit-III is interrupted by a distinct peak at a depth of $268 \mathrm{~cm}$. XRF scanning provided intensity records of the elements $\mathrm{Si}, \mathrm{K}, \mathrm{Ca}, \mathrm{Ti}$ and $\mathrm{Fe}$, as well as $\mathrm{Cr}_{\text {inc }}$ and $\mathrm{Cr}_{\text {coh. }}$. The main geochemical variations of core Strze3a and lithological Units I-III were examined by exploration of the center-log-ratio transformed XRF-data using biplots (Fig. 4). Biplots present the distribution of the geochemical element and the XRF scanning data with respect to the first and second principal components (PCs). Positively correlated variables/elements point in the same direction, whereas negatively correlated elements are located oppositely. The vector length of the variables indicates the strength of the variables but is also sensitive to 


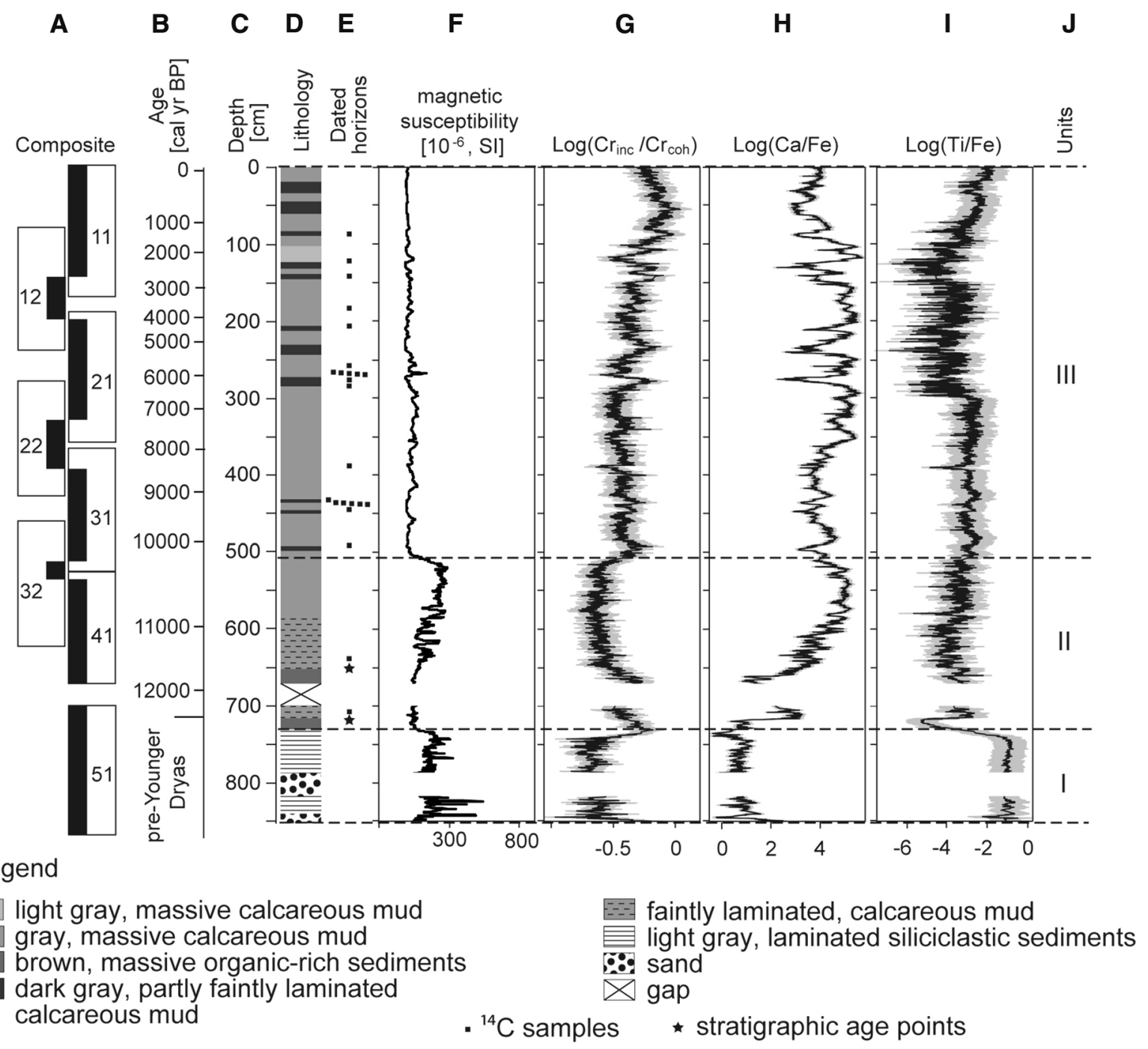

Fig. 3 Sedimentology and geochemistry of the investigated sediment core. The figure includes: a parts used from the twin cores for the core composite construction marked by black bars; b age scale based on the age-depth model shown in Fig. 2; c sediment depth scale; d sediment lithology; e positions of samples for ${ }^{14} \mathrm{C}$ datings and horizons included in the age model;

elements with low count rates and high noise levels. To avoid misinterpretations introduced by analytical noise, the vector lengths were scaled by the precision of the elements using the replicate measurements (Weltje et al. 2015).

The biplot of core Strze3a (Fig. 4a) shows three main groups of elements differentiating the element $\mathrm{Ca}$, the variables $\mathrm{Cr}_{\text {inc }}$ and $\mathrm{Cr}_{\text {coh }}$ and the elements $\mathrm{K}$, $\mathrm{Ti}, \mathrm{Si}$ and $\mathrm{Fe}$. The element $\mathrm{Ca}$ represents the variations of calcite and is negatively correlated with the f magnetic susceptibility; $\mathbf{g}$-i elemental ratios and properties revealed from XRF scanning. Shaded area indicates the 95\% confidence level calculated from replicate measurements; $\mathbf{j}$ units determined on the basis of lithological and geochemical properties

siliciclastic elements. This indicates that calcite is not of siliciclastic origin but is rather authigenically formed. The third group of elements is represented by $\mathrm{Cr}_{\text {inc }}$ and $\mathrm{Cr}_{\text {coh }}$ and reflects the Compton $\left(\mathrm{Cr}_{\text {inc }}\right)$ and Rayleigh $\left(\mathrm{Cr}_{\mathrm{coh}}\right)$ scattering of the primary radiation. The elements $\mathrm{K}$ and $\mathrm{Ti}$ are lithogenic elements, whereas $\mathrm{Si}$ can represent both siliciclastic minerals (e.g., aluminium-silicates, quartz) and biogenic silica. The redox-sensitive element Fe is commonly supplied by lithogenic sediments or groundwater but is often 


\section{Core Strze-3a}
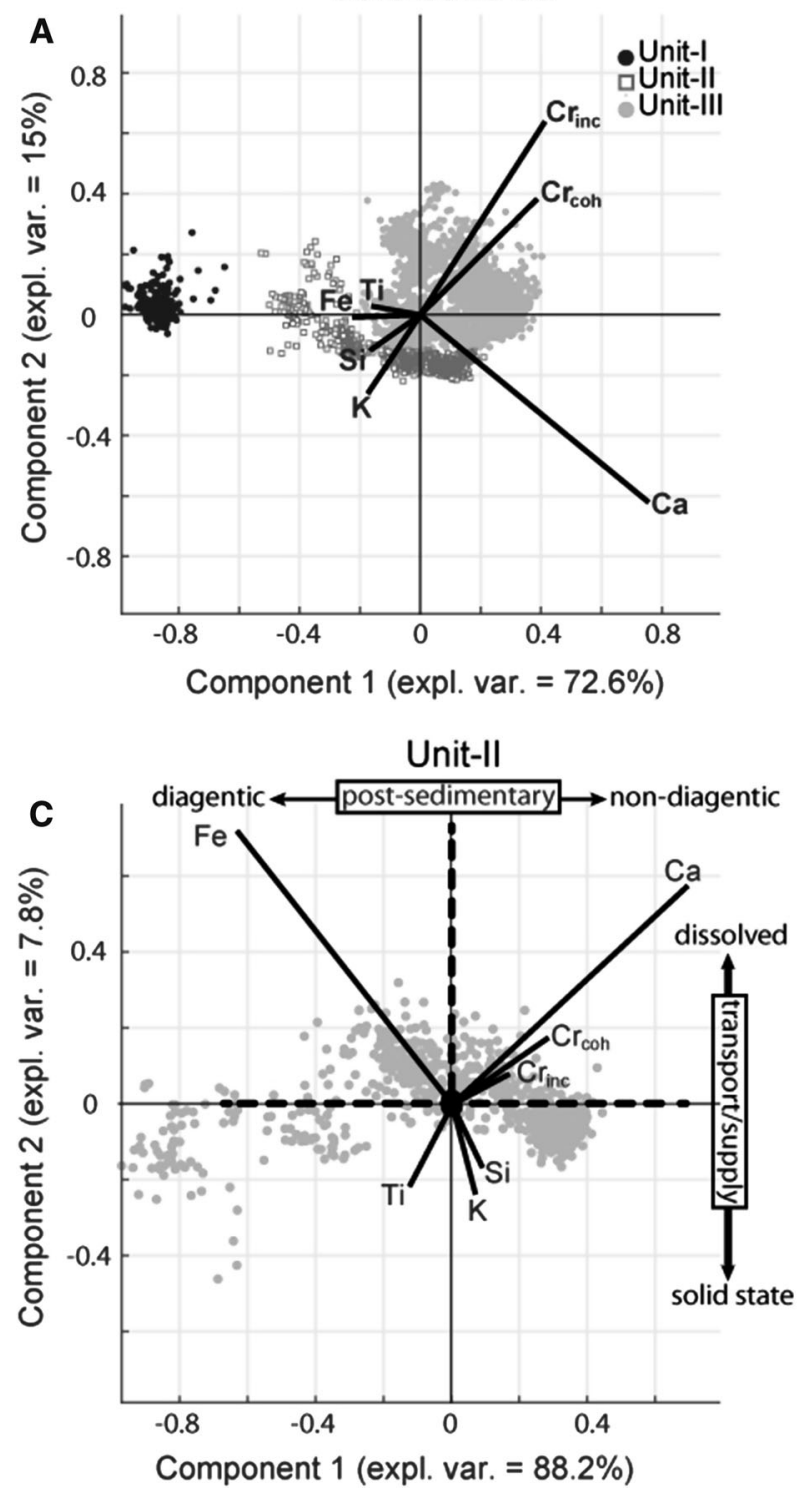

Unit-I

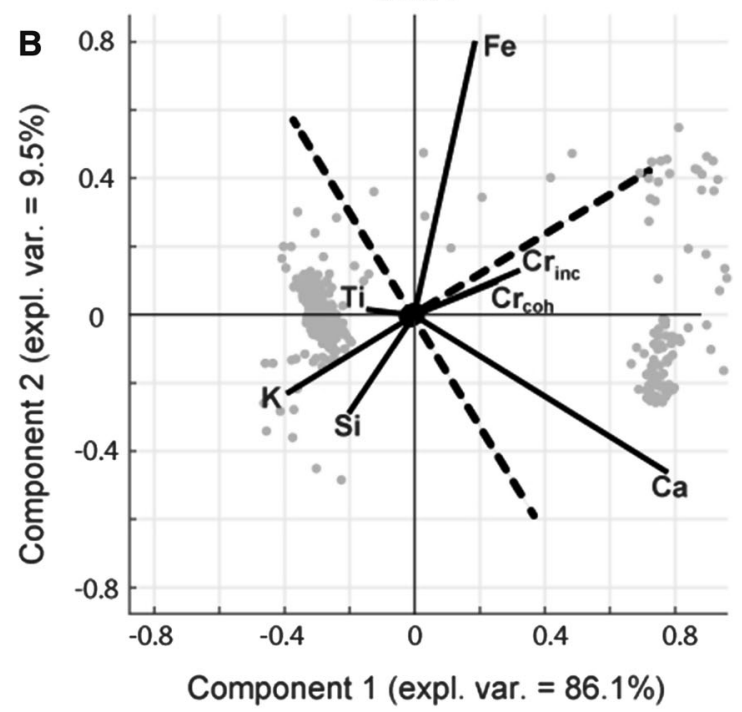

Unit-III

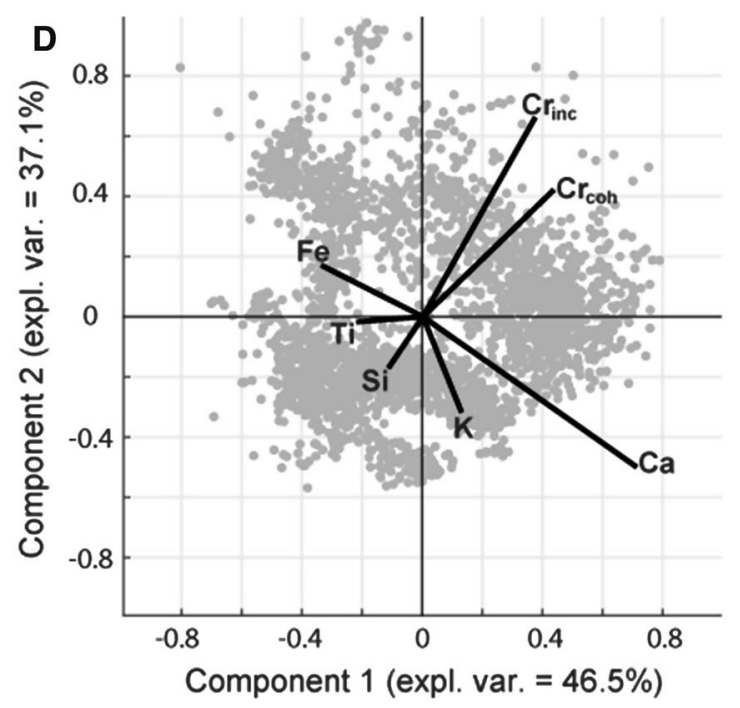

Fig. 4 Principal component analysis (PCA) biplots derived from XRF scanning data. Dashed lines on $\mathbf{b}$ and $\mathbf{c}$ indicate three different syn- and post-sedimentary processes related to particular groups of elements

altered by post-sedimentary digenesis in sub- and anoxic lakes (Boyle 2001).

The heterogeneous distribution of the data points revealed by the biplot of core Strze3a (Fig. 4a) indicates relatively large compositional differences between the different lithological units. Therefore, the more homogenous lithological units are examined individually for a more reliable representation of the compositions. The biplot of Unit-I (Fig. 4b) shows an negative correlation between $\mathrm{Ca}, \mathrm{Cr}_{\text {inc }}$ and $\mathrm{Cr}_{\text {coh }}$ on the one hand and the siliciclastic elements $\mathrm{Ti}, \mathrm{Si}$ and $\mathrm{K}$ on the other. These elements dominate of the first PC, whereas Fe that is not clearly related to any of the other elements dominates the second PC. The deviation between $\mathrm{Ti}$ and $\mathrm{Si}$ suggests that $\mathrm{Si}$ reflects a mixture of siliciclastic sediments and biogenic silica. A similar distribution is shown for Unit-II, although the influence of the siliciclastic elements seems weaker in this unit (Fig. 4c). Unit-III reveals a negative correlation between the elements $\mathrm{Ca}$ and $\mathrm{Fe}$, between the 
variables $\mathrm{Cr}_{\text {inc }}$ and $\mathrm{Cr}_{\mathrm{coh}}$ and between the elements $\mathrm{Ti}$, $\mathrm{Si}$ and K (Fig. 4d). The short loading vectors of Fe, Ti, $\mathrm{Si}$ and $\mathrm{K}$ suggest that these elements play only a minor role. Unlike the other stratigraphic units, unit-III reveals a more or less positive correlation between the elements $\mathrm{Fe}$ and $\mathrm{Ti}$. The deviation between $\mathrm{Ti}$ and $\mathrm{Si}$ can be explained by the contribution of biogenic silica, whereas the orientation of $\mathrm{K}$ can be explained by the low amounts of siliciclastic sediment and high calcium carbonate concentrations. The positive correlation between $\mathrm{Ca}$ and $\mathrm{K}$ is a typical artefact for carbonaterich sediments resulting from the partly overlapping energy lines of $\mathrm{K}$ and $\mathrm{Ca}$ in the XRF spectrum.

Based on the elemental correlations revealed by the biplots, the main compositional variations can be summarized by $\log$-ratios of $\mathrm{Ca} / \mathrm{Fe}, \mathrm{Ti} / \mathrm{Fe}$ and $\mathrm{Cr}_{\text {ind }} /$ $\mathrm{Cr}_{\text {coh. }}$. Confidence limits of the XRF scanning results were calculated for each ratio pair using replicate measurements. All XRF records show a strong change at the boundary between the predominantly siliciclastic sediments of Unit-I and the organic-rich muds of Unit-II (Fig. 3). Within Unit-II, the Ti/Fe values remain constant, while the $\mathrm{Ca} / \mathrm{Fe}$ values decrease up to a $665 \mathrm{~cm}$ depth, increase again between 665 and $655 \mathrm{~cm}$ and then stabilize above. In contrast, the $\mathrm{Cr}_{\text {ind }} /$ $\mathrm{Cr}_{\text {coh }}$ values are relatively high up to a $655 \mathrm{~cm}$ depth, decrease between 665 and $655 \mathrm{~cm}$ and remain low throughout the upper part of Unit-II. The boundary between Unit-II and Unit-III is indicated by an increase in the $\mathrm{Cr}_{\text {inc }} / \mathrm{Cr}_{\text {coh }}$ record and a decrease in the $\mathrm{Ca} / \mathrm{Fe}$ records (Fig. 3g, h). Unit-III reveals relatively high $\mathrm{Cr}_{\text {inc }} / \mathrm{Cr}_{\text {coh }}$ and $\mathrm{Ca} / \mathrm{Fe}$ values with several distinct and more-abrupt variations that correspond to dark gray sediment layers. The $\mathrm{Ti} / \mathrm{Fe}$ record is relatively constant throughout Unit-III, with a slight drop between 80 and $300 \mathrm{~cm}$ followed by a gradual rise. Low concentrations of siliciclastic sediments and $\mathrm{Ti}$ values cause large uncertainties between 80 and $300 \mathrm{~cm}$ (Fig. 3). With respect to the complete core, variations in the $\mathrm{Ca} / \mathrm{Fe}$ are generally negatively correlated with the $\mathrm{Cr}_{\text {inc }} / \mathrm{Cr}_{\text {coh }}$ record.

Pollen and Phytoplankton analysis

Pollen analysis reveals four main phases of vegetation development (Fig. 5). The first (approximately $750-540 \mathrm{~cm}$ depth) represents a high amount of pioneer tree species Pinus and Betula with admixture of heliophilous herbs such as Artemisia. The lowermost sample revealed the presence of Hippophä rhamnoides, which is characteristic for Late Glacial vegetation of the Bølling/Allerød period. Non-arboreal pollen (NAP) constitutes approximately $6 \%$ of the calculation sum AP $+\mathrm{NAP}=100 \%$. Pinus and $B e$ tula are characterized by a distinct minimum of the latter and a concurrent maximum of the former between 720 and $665 \mathrm{~cm}$. The main feature of the second phase (approximately $540-220 \mathrm{~cm}$ depth) is a high contribution of deciduous trees such as Alnus, Corylus avellana and Quercus that coincide with NAP minima. The third phase (approximately $220-80 \mathrm{~cm}$ depth) reveals a spread of Carpinus betulus and a decrease in Corylus avellana. This phase shows a decreasing concentration of AP and a concurrent appearance of Plantago lanceolata and, later, Secale cereale. Finally, the fourth phase (approximately $80-0 \mathrm{~cm}$ depth) shows a remarkable increase of herbaceous plants, mainly synanthropic taxa.

Phytoplankton in the lower part $(>400 \mathrm{~cm})$ of the core consists predominantly of Tetraedron and small amounts of Botryococcus (Fig. 5). Phytoplankton remains are rare above $400 \mathrm{~cm}$, apart from the uppermost $80 \mathrm{~cm}$ of the core, where Pediastrum increases.

\section{Discussion}

\section{Chronology}

The chronology of core Strze 3a was constructed using 22 selected radiocarbon dates (Fig. 2). Reworking of older material probably contaminated the organic matter that was deposited during the onset and early stages of lake sedimentation. This explains the large offset ( $>1000$ years) indicated by the lowermost samples Poz-77052 and Poz-71066 with respect to the onset of lake sedimentation in this region (Kaiser et al. 2012; Michczyńska et al. 2013) and the biostratigraphy obtained from pollen. Therefore these two dating points were excluded. The soluble and residual carbon fractions were analysed separately in a selected core interval between $266 \mathrm{~cm}$ and $284.5 \mathrm{~cm}$ in order to assign precise age of the magnetic susceptibility peak at a depth of $268 \mathrm{~cm}$, as well as to check for potential lake reservoir effect. The calibrated 2-sigma age ranges for both fractions overlap or are very close to each other (Table 1), suggesting small impact of 


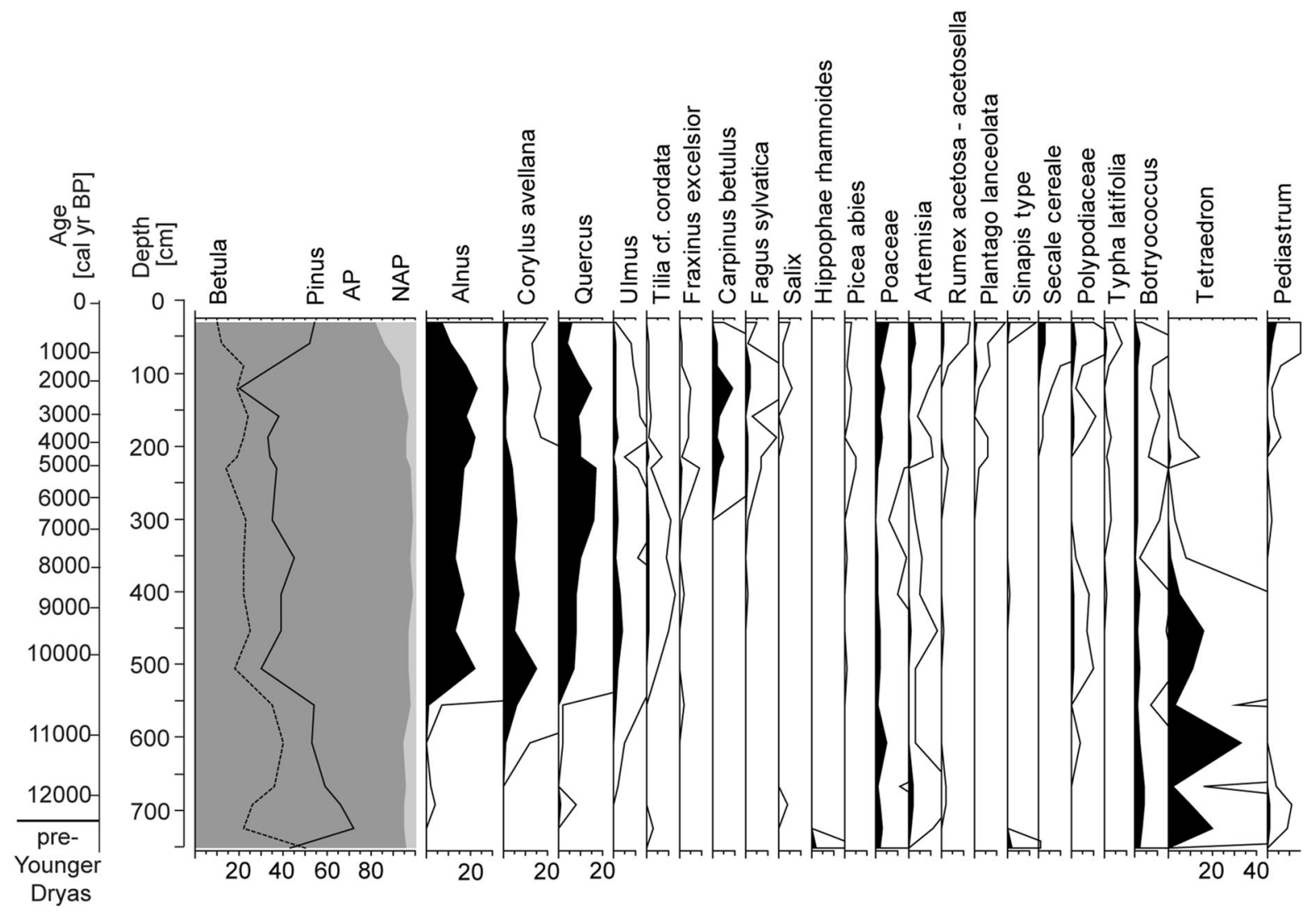

Fig. 5 Pollen percentage diagram. The outline curves represent a $10 \times$ exaggeration. $A P$ arboreal pollen, NAP non-arboreal pollen

reservoir effect on the dates. However, the soluble fraction ages in the section are very similar and all of their 2-sigma ranges overlap, while the residual fraction ages are generally older in deeper samples and younger in the upper. This core interval shows a transition between massive grey calcareous mud and darker, organic-rich, calcareous mud. According to Hanebuth et al. (2009) soluble carbon fraction samples can provide slightly biased ages due to the diffusion of acids from organic-rich sediments into adjacent sediments. This may be also true for the present case. Therefore, the residual fraction ${ }^{14} \mathrm{C}$ dates were taken for age modelling. However, when soluble carbon fraction samples were included instead of residual fraction ${ }^{14} \mathrm{C}$ dates for the cross-checking of the results, the final model output was very similar.

Due to a lack of reliable dates for the bottom part of the core, its chronology is based on distinct litho- and geochemical boundaries combined with changes in pollen profiles. The changes of Betula and Pinus concentrations at this depth (Fig. 5) additionally support our assumptions, as they show similar patterns as those already recognized for this time period in Poland and eastern Germany (Enters et al. 2010; Milecka et al. 2011). The onset and termination of the Younger Dryas in Poland have been dated accordingly at 12,650 and 11,520 cal yr BP (Goslar 1998), which we match with the clear changes in geochemical profiles at 715 and $655 \mathrm{~cm}$, respectively (Fig. 3). However, the large age uncertainty of the lower part of the sediment record prevents detailed climate reconstruction.

XRF data interpretation

Information about element distributions and compositional variations is obtained from biplot analyses after log-transformation of the elemental records (Fig. 4). However, appropriate interpretations of the bulk geochemical records in terms of climatic proxies require complementary sedimentological information from microscope analysis of thin sections and smear 
slides. The elements $\mathrm{Ti}$ and $\mathrm{Ca}$ are negatively correlated throughout all of the stratigraphic units of core Strze3a (Fig. 4). Thin section and smear slide observations confirm that the element $\mathrm{Ti}$ is related with the siliciclastic fraction and that $\mathrm{Ca}$ is constrained to authigenically formed calcite. The redox-sensitive element $\mathrm{Fe}$ appears uncorrelated with either $\mathrm{Ti}$ or $\mathrm{Ca}$ in Unit-I and Unit-II (Fig. 4b, c), but it is slightly positively correlated with $\mathrm{Ti}$ and negatively correlated with Ca in Unit-III (Fig. 4d). According to the $\log (\mathrm{Ti} /$ $\mathrm{Fe}$ ) record, the amount of $\mathrm{Fe}$ is relatively low in Unit-I and not clearly constrained to the siliciclastic sediment fraction. Lower $\log (\mathrm{Ti} / \mathrm{Fe})$ ratios suggest a relative increase in the Fe concentrations in Unit-II, but the correlation amongst $\mathrm{Fe}$, the element $\mathrm{Ca}$ and the siliciclastic elements $\mathrm{Si}, \mathrm{K}$, Ti remained unchanged (Fig. 4c). The decoupling of Fe and the siliciclastic elements in Units I and II could indicate the supply of $\mathrm{Fe}^{2+}$ by iron-rich groundwater discharge from aquifers in Quaternary deposits (Szczucińska 2016). The dissolved Fe supplied to the lake from the catchment is often involved in the precipitation of iron (hydr)oxides when the water column overturns (Schettler et al. 1999; Boyle 2001; Bonk et al. 2015). At present, such seasonal overturning of the lake occurs twice per year in Lake Strzeszyńskie (Jańczak and Sziwa 1995). However, microscope observations show that Feminerals are mostly abundant as iron-sulfide framboides, indicating post-sedimentary iron reduction and overprinting the initial iron minerals deposited.

The differentiation of $\mathrm{Ti}, \mathrm{Ca}$ and $\mathrm{Fe}$ indicated by the biplots supports the different syn- and post-sedimentary processes reflected by these elements (Fig. 4). Although the biplots reveal a rotation, the correlations amongst $\mathrm{Ti}, \mathrm{Ca}$ and $\mathrm{Fe}$ are fairly similar for Units I and II. The negative correlation between silicate element $\mathrm{Ti}$ and the elements $\mathrm{Ca}$ and $\mathrm{Fe}$ can be explained by sediment and ground water supply, respectively. The deviation between $\mathrm{Ca}$ and $\mathrm{Fe}$ can be explained by postsedimentary iron reduction, which does not occur for calcite. Microscopic observations in Units II and III reveal the presence of diagenetic iron-sulphide minerals that commonly form under euxinic conditions (Boyle 2001). Fe and $\mathrm{Ti}$ are positively related, suggesting that iron-sulphur reduction occurred in the sediment and with minimal remobilization.

Variations in the $\mathrm{Cr}_{\text {inc }} / \mathrm{Cr}_{\text {coh }}$ are related to the average atomic number of the sample or the relative sample attenuation (Croudace et al. 2006). The relevance of $\mathrm{Cr}_{\text {coh }}$ and $\mathrm{Cr}_{\text {inc }}$ is weak in Unit-I, indicating that variations in bulk sediment attenuation do not play a dominant role in this part of the core. Unit-II reveals a positive correlation between $\mathrm{Cr}_{\text {coh }}$ and $\mathrm{Cr}_{\text {inc }}$ with $\mathrm{Ca}$, suggesting that variations in the carbonate content dominate changes in the bulk sediment attenuation. In contrast, $\mathrm{Cr}_{\text {inc }}$ and $\mathrm{Cr}_{\text {coh }}$ in Unit-III are not related to $\mathrm{Ca}$ or the siliciclastic elements $\mathrm{Si}, \mathrm{K}$, and $\mathrm{Ti}$ (Fig. 4). Therefore, the variations of $\mathrm{Cr}_{\mathrm{inc}}$ and $\mathrm{Cr}_{\text {coh }}$ are thought to reflect variations of organic matter, which, according to microscopic observations, is the principal non-siliciclastic and non-calcareous sediment fraction in this part of the core. This interpretation is supported by high $\log \left(\mathrm{Cr}_{\text {inc }} / \mathrm{Cr}_{\text {coh }}\right)$ values that correspond with distinct organic-rich layers. It is also supported by several previous studies showing $\mathrm{Cr}_{\text {inc }} / \mathrm{Cr}_{\text {coh }}$ as a potential proxy for organic matter variations in organic-rich lacustrine sediments (Guyard et al. 2007; Jouve et al. 2013).

Changes in lake sedimentation during the Late Pleistocene and Holocene

The retrieved sediment core likely reveals the complete record of the lake evolution from its origin shortly after the retreat of the Scandinavian Ice Sheet from the Poznań phase position at around $18.5 \mathrm{ka} \mathrm{BP}$ (Kozarski 1995). The lowermost sand layers of Unit-I are most likely a record of this phase when fluvioglacial sediments were deposited by melt-water rivers or dead ice melting. The following laminated fine-grained sediments at $\sim 790-731 \mathrm{~cm}$ are interpreted as the initial lake sedimentation. The pollen biostratigraphy reveals that the onset of organic-rich lake sedimentation at approximately $731 \mathrm{~cm}$ occurred during the warm Bølling or Allerød period. This section also shows a strong reduction in siliciclastic sediments, but no formation of authigenic calcite. The strong rise in $\log (\mathrm{Ca} / \mathrm{Fe})$ at $720 \mathrm{~cm}$ indicates the change from organic-rich to faintly laminated calcareous mud (Fig. 3h). This transition matches the onset of the YD, although the exact timing remains ambiguous due to the relatively large chronological uncertainties in this part of core Strze3a. The deposition of authigenic carbonates during the YD suggests environmental changes within the lake such as temperature, $\mathrm{pH}$ and $\mathrm{Ca}$-saturation. The lake conditions further evolved toward the Holocene as reflected by the 
distinct increase of organic matter content on account of carbonates in overlaying sediments (between 665 and $654 \mathrm{~cm}$ depth) that, according to our age-depth model (Fig. 2), represent later part of the of the YD. If our age estimations for this part of the core are correct, then YD appears to be distinguished by highly unstable lake sedimentation.

Holocene sediments are characterised by an increasing carbonate content reflected by $\log (\mathrm{Ca} / \mathrm{Fe})$ record in lithologic Unit-II (Fig. 3). The relatively high carbonate content and the concurrent development of Pinus-Betula forest (Fig. 5) is commonly reported for lakes of Poland and eastern Germany during this period, which has been associated with nutrient fixation in developing soils (Ralska-Jasiewiczowa et al. 1998; Enters et al. 2010; Apolinarska et al. 2012; Pedziszewska et al. 2015). The partly preserved laminations suggest that calcite precipitation was controlled by seasonal lake internal variations.

The transition from Unit-II to Unit-III at around 10,200 cal yr BP shows a shift to more-organic sediments, possibly associated with the development of more dense deciduous forest, as indicated by Alnus, Corylus, Quercus and Ulmus pollen profiles (Fig. 5). This shift occurring in correspondence to distinct magnetic susceptibility drop (Fig. 3f) suggesting the reductive diagenesis of magnetic iron oxides likely triggered by organic matter decomposition and related oxygen depletion in sediment-water interface (Snowball 1993). The transition from Unit-II to Unit-III is followed by the long-lasting (until ca. $1600 \mathrm{cal}$ yr BP) period with stable depositional conditions in the lake. The only evident changes are relatively short periods represented by the layers distinctly enriched in organic matter and depleted in carbonates, and a distinct peak in magnetic susceptibility around $5.9 \mathrm{kyr}$ cal BP. The latter might coincide with the nearby Morasko iron meteorite shower that took place before 4.9-5.3 kyr cal BP (Stankowski 2008) and that resulted in the formation of several impact craters up to $100 \mathrm{~m}$ wide located approximately $5.7 \mathrm{~km}$ NE of Lake Strzeszyńskie. However, a lack of concurrent changes in sediment characteristics reveals that the environmental consequences of this event were probably restricted, as also suggested by the meteorite impact numerical modelling (Bronikowska et al. 2017).

After ca. 1600, there is a higher contribution of anthropogenic indicators in the local flora (Fig. 5) that coincide with more organic sediments. This may be explained as the effect of enhanced erosion and higher trophy caused by deforestations and human activity within the catchment.

Lake-level changes during the Holocene

The transition from Unit-II to Unit-III at ca. $10,200 \mathrm{cal}$ yr BP is followed by the long-lasting stable lake sedimentation conditions (Fig. 3) and minor vegetation shifts (Fig. 5). The massive gray calcareous mud with intercalations of faintly laminated dark calcareous mud dominates the sedimentary record of Unit-III. These intercalations correspond to minima in $\log (\mathrm{Ca} / \mathrm{Fe})$ and to increased $\log \left(\mathrm{Cr}_{\text {inc }} / \mathrm{Cr}_{\text {coh }}\right)$ (Fig. 3). Similar variations have been observed in postglacial lakes in Northern Germany, which are situated in a similar glaciofuvial landscape (Dietze et al. 2016). The relative calcite variations observed in the lake sediments of Lake Strzeszyńskie could be linked to lake-level fluctuations, where periods of elevated water level correspond to lower calcite content in sediments. Calcite precipitation decreases during times when lake levels are high due to: (1) the saturation of $\mathrm{Ca}^{2+}$ being lower due to a larger water volume; (2) more energy being required for heating the lake to reduce the solubility of $\mathrm{CaCO}_{3}$; (3) flooded shores providing extra organic acid input, which contributes to decreasing $\mathrm{pH}$; (4) an elevated lake level associated with a cold period, in which case a low water temperature favours solubility of $\mathrm{CO}_{2}$, leading to a lower $\mathrm{pH}$. It should be also stressed that the carbonate record is not linearly linked to lake-level changes (Ohlendorf et al. 2013); hence, we do not imply the amplitude of changes and confine our interpretation to the most pronounced minima relating to dark gray calcareous mud layers.

Altogether, we recognized 9 periods of high effective precipitation, and we numbered them from youngest to oldest (Fig. 6). Layer no. 9 falls within the period around $10.1 \mathrm{kyr}$ cal BP. This coincides well with the wetter phase in Poland at that time (Starkel et al. 2013) as well as with high water levels in the Jura mountains (Magny 2004). According to Pędziszewska et al. (2015), who found a similar record in Suminko Lake sediments (Fig. 1b), the aforementioned wet phase could be related to a cold period triggered by a distinct disturbance of termohaline circulation that took place 
in the north Atlantic Ocean at the same time (Bond et al. 1997; Björck et al. 2001; Sternal et al. 2014).

The next phase in the Lake Strzeszyńskie sediments is marked by the pair of dark gray layers that were dated to the period around $9.3 \mathrm{kyr}$ cal BP. These layers are well correlated with wet conditions identified in other records at the same time (Fig. 6). Gałka and Apolinarska (2014) suggest that the high lake levels in northern Poland during this period could have been triggered by the change in the atmospheric circulation in the region due to the final decay of the Scandinavian Ice Sheet (Lauterbach et al. 2011). However, because the lakes located significantly more to the south-west show the same trend (Magny 2004), these high levels might be due, at least partly, to other factors.

Phases no. 7 (6.4-6.1 kyr cal BP) and 6 (5.5-5.1 kyr cal BP) correlate well with the high lake-levels in central Europe (Fig. 6d, g) in contrast with phase no. 5 (4.7-4.5 kyr cal BP). However, all match known Polish wet phases (Fig. 6d, e). Moreover phases no. 7 and 5 falls within the periods of reduced solar activity (Wanner et al. 2011). However, whether this contributed to the observed changes in the Lake Strzeszyńskie sediments remains unclear, since some authors suggest even slight warming in Europe during these periods (Alverson et al. 2003; Wanner et al. 2011).

Phase no. 4 (2.7-2.4 kyr cal BP) is marked by two separate dark gray layers with two distinct $\log (\mathrm{Ca} / \mathrm{Fe})$ minima. It is well correlated with twofold maxima of a quantified testate amoebae-inferred wetness reconstruction from northern Poland. Also, data from other sites in Poland and Europe correspond well to our record (Fig. 6). The period around $2.7 \mathrm{kyr}$ cal BP is

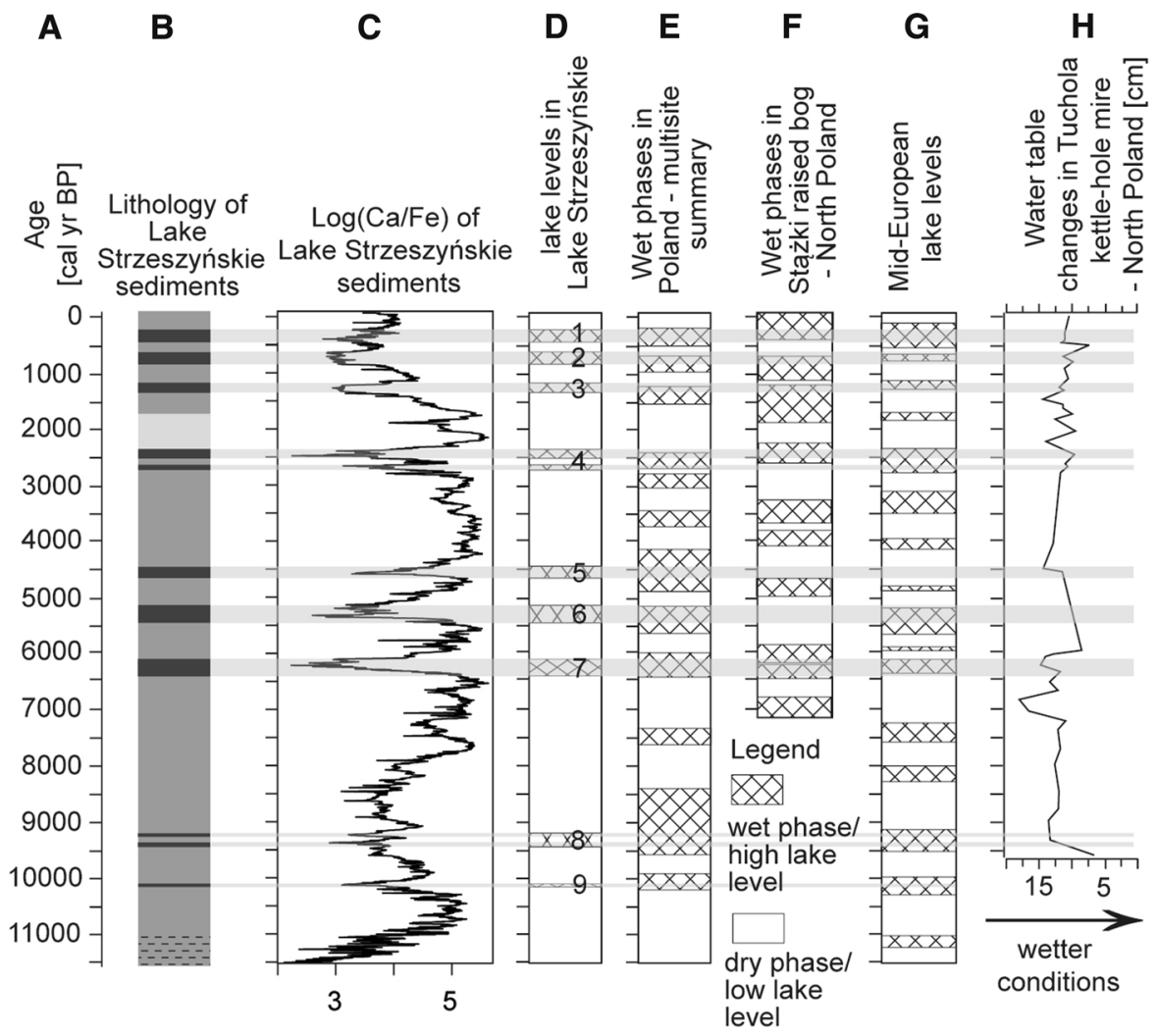

Fig. 6 Holocene lake levels reconstructed in the present study compared to various wetness records in Poland and Europe. a Age scale; b lithology of the Holocene part of the Lake Strzeszyńskie sediment core (see Fig. 3 for a legend); $\mathbf{c} \log (\mathrm{Ca} /$ $\mathrm{Fe}$ ) profile of the Lake Strzeszyńskie sediment core; $\mathbf{d} 9$ elevated lake-level periods recognized in the Lake Strzeszyńskie sediment profile on the basis of distinct lithological changes and $\log (\mathrm{Ca} / \mathrm{Fe})$ minima (see text for discussion); e reconstruction derived from various geological archives (Starkel et al. 2013); f reconstruction based on plant macrofossils and testate amoebae (Gałka et al. 2013); g multi-site summary (Magny 2004); h testate amoebae-derived quantitative water table reconstruction (Lamentowicz et al. 2008) 
also known as one of the major cold phase in the Holocene (Wanner et al. 2011).

The remaining three periods indicated in Fig. $6 \mathrm{~d}$ co-occur with a period of increasing human activity in the catchment region. However, all periods match known central European wet phases (Fig. 6e-h), indicating that these may not be only local variations. Phase no. 3 (ca. 1.3-1.2 kyr cal BP) correspond to the prominent total solar irradiance minimum at ca. $1.3 \mathrm{kyr}$ cal BP (Steinhilber et al. 2009) and falls within Dark Age or Migration Period Cooling dated to ca. 300-800 AD (1.75-1.15 kyr cal BP; Ljungqvist 2010). Phase no. 2 and 1 (0.8-0.6 and 0.4-0.2 kyr cal $\mathrm{BP}$, respectively), in turn, correlate with the Little Ice Age (ca. 0.7-0.15 kyr cal BP; Wanner et al. 2011), one of the coldest Holocene periods, characterized by synchronisation of solar activity minima and volcanic eruptions, interrupted by some warmer periods (Wanner et al. 2011). The latter might explain the discontinuity of high lake-level stands in Lake Strzeszyńskie during the Little Ice Age.

The Strzeszyńskie record reveals 9 periods of elevated lake levels marked by faintly laminated dark calcareous mud layers and corresponding $\log (\mathrm{Ca} / \mathrm{Fe})$ minima that occurred irregularly and lasted from several tens to several hundred years. The periods between these wet shifts varied from 200 to nearly 3000 years but are most frequent over the last 2500 yrs. These long intervals without a record of elevated lake-water periods in Lake Strzeszyńskie (9.2-6.4 and 4.5-2.7 kyr cal BP) are known to consist of several wetter climate phases, as shown by records in other lakes and regions (Fig. 6). This difference may be due to a smaller magnitude of these climate shifts in the study region. There are some fluctuations of $\log (\mathrm{Ca} /$ $\mathrm{Fe}$ ) in the record that may be interpreted as minima, but they lack the corresponding sedimentary dark gray layers. Consequently, even if these minima correlate well with the previously recognized wet periods in other archives, we do not indicate them as such in our record. This is because such subtle changes may be related to other catchment-scale changes, e.g., in nutrient delivery due to wildfires.

Apart from the dark gray calcareous mud layers, the light gray calcareous mud layer dated to ca. 2.3-1.7 kyr cal BP and characterised by low $\log \left(\mathrm{Cr}_{\text {inc }} /\right.$ $\left.\mathrm{Cr}_{\text {coh }}\right)$ and high $\log (\mathrm{Ca} / \mathrm{Fe})$ (Figs. 4, 6) is clear in the record. It is considered to represent a particularly dry and/or warm period. Indeed, this 600-year-long period corresponds to the warm Roman Iron Age (PAGES 2k Consortium 2013), when Poland was known to be dry (Lamentowicz et al. 2008), with the exception of a short-lived cold shift at ca. $2 \mathrm{kyr}$ cal BP (Pędziszewska et al. 2015). In Lake Strzeszyńskie, it was likely a period of lower trophy and enhanced mixing. The former is expressed by decreased organic matter content in sediments as well as by a dominance of chrysophytes that indicates oligotrophic conditions with limited nutrient availability (Cohen 2003). The low nutrient input to the lake at that time could have been due to the reduced erosion within the catchment due to decreased precipitation. The inferred enhanced mixing, in turn, could be the result of a lowered lake level that can be assumed due to higher evapotranspiration and decreased meteoritic water input. The better oxygenation of lake waters triggered by enhanced mixing could lead to efficient organic matter mineralization (Bloesch 2004). The feature that strengthened our inference about climatically driven sedimentation during the Roman Iron Age is the short-lived increase in organic matter content at ca. $1.9 \mathrm{kyr}$ cal BP. Taking into account possible age model uncertainties this may correspond to the aforementioned short-lived cold shift.

The observed changes in the sedimentary record of Lake Strzeszyńskie seem to be largely triggered by regional and by global hydroclimatic shifts. The clear evidence of only some of the already reported wet and/ or cold periods throughout the Holocene may be due to the variable local magnitudes of these climatic changes and might suggest the regional variability in overall similar paleoclimatic trends over Europe. As suggested by Magny (2004) in his compilation of central European lake levels, these trends may reflect global-scale variability expressed, for instance, as the so-called Bond cycle (Bond et al. 1997).

\section{Conclusions}

The Late Pleistocene and Early Holocene sediments of Lake Strzeszyńskie precisely mark the main events and processes that influenced sedimentation within the lake. Changes in the lake deposition are associate with climatically and environmental variations within the catchment, such as soil and vegetation development. After the establishment of dense deciduous forest at ca. $10,200 \mathrm{cal} \mathrm{yr} \mathrm{BP}$, the long-lasting stage of 
stable lake sedimentation prevailed. This stage was terminated at ca. $1600 \mathrm{cal} \mathrm{yr} \mathrm{BP,} \mathrm{when} \mathrm{within-catch-}$ ment deforestations and related enhanced erosion caused a higher trophy in the lake.

The Holocene period is marked by nine episodes of elevated lake level. These episodes revealed distinctly more organic and less calcareous lake sedimentation, accompanied by enhanced Fe deposition. The ages of nine elevated lake levels (ca. 10.1, 9.3, 6.4-6.1, 5.5-5.1, 4.7-4.5, 2.7-2.4, 1.3-1.2, 0.8-0.6, $0.4-0.2$ kyr cal BP) show significant correlation with wetter periods recognized in several records from Poland and central Europe. They also partly coincide with well-established supraregional cold periods, including the Bond cycle, which implies that they were largely triggered by regional and global climatic shifts.

Acknowledgements The study was financed through a grant from the National Science Centre (NCN), Grant No. 2013/09/B/ ST10/01666. We would like to express our gratitude to Michał Woszczyk and to all who helped during the fieldwork. Brian Brademann is acknowledged for preparation of thin sections, Monika Panfil for pollen analysis, and Tomasz Goslar and his team for ${ }^{14} \mathrm{C}$ measurements. We also thank the editor and two anonymous reviewers for their constructive comments.

Open Access This article is distributed under the terms of the Creative Commons Attribution 4.0 International License (http:// creativecommons.org/licenses/by/4.0/), which permits unrestricted use, distribution, and reproduction in any medium, provided you give appropriate credit to the original author(s) and the source, provide a link to the Creative Commons license, and indicate if changes were made.

\section{References}

Alverson KD, Bradley RS, Pedersen TF (2003) Paleoclimate, global change and the future. Springer, New York

Apolinarska K, Gałka M (2017) Detrital input to spring-fed fen deposits: a problem or an opportunity in palaeoenvironmental studies? A Holocene palaeoclimatic reconstruction from central Europe. J Quat Sci 32:91-103

Apolinarska K, Woszczyk M, Obremska M (2012) Late Weichselian and Holocene palaeoenvironmental changes in northern Poland based on the Lake Skrzynka record. Boreas 41:292-307

Berglund BE, Ralska-Jasiewiczowa M (1986) Pollen analysis. In: Berglun BE (ed) Handbook of holocene palaeoecology and palaeohydrology. Wiley, Chichester, pp 455-483

Björck S, Muscheler R, Kromer B, Andresen CS, Heinemeier J, Johnsen SJ, Conley D, Koç N, Spurk M, Veski S (2001) High-resolution analyses of an early Holocene climate event may imply decreased solar forcing. Geology 29:1107-1110

Blaauw M, Christen JA (2011) Flexible paleoclimate age-depth models using an autoregressive gamma process. Bayesian Anal 6:457-474

Bloesch J (2004) Sedimentation and lake sediment formation. In: O'Sullivan PE, Reynolds CS (eds) The Lakes handbook: limnology and limnetic ecology. Wiley-Blackwell, London, pp 197-229

Bond G, Showers W, Cheseby M, Lotti R, Almasi P, Priore P, Cullen H, Hajdas I, Bonani G (1997) A pervasive millennial-scale cycle in North Atlantic Holocene and glacial climates. Science 278:1257-1266

Bonk A, Tylmann W, Amann B, Enters D, Grosjean M (2015) Modern limnology and varve-formation processes in Lake Żabińskie, northeastern Poland: comprehensive process studies as a key to understand the sediment record. J Limnol 74:358-370

Boyle JF (2001) Inorganic geochemical methods in paleolimnology. In: Last WM, Smol JP (eds) Tracking environmental change using lake sediments. Physical and geochemical methods, vol 2. Kluwer Academic Publishers, Dordrecht, pp 83-141

Brauer A, Casanova J (2001) Chronology and depositional processes of the laminated sediment record from Lac d'Annecy, French Alps. J Paleolimnol 25:163-177

Brock F, Higham T, Ditchfield P, Ramsey CB (2010) Current pretreatment methods for AMS radiocarbon dating at the Oxford Radiocarbon Accelerator Unit (ORAU). Radiocarbon 52:103-112

Bronikowska M, Wünnemann K, Artemieva N (2017) Reconstruction of the Morasko meteoroid impact: insight from numerical modeling. Meteorit Planet Sci. doi:10.1111/ maps. 12882

Cohen AS (2003) Paleolimnology: the history and evolution of lake systems. Oxford University Press, New York

Croudace IW, Rindby A, Rothwell RG (2006) ITRAX: description and evaluation of a new multi-function X-ray core scanner. In: Rothwell RG (ed) New techniques in sediment core analysis. Geological Society, London, pp 51-63

Dietze E, Słowiński M, Zawiska I, Veh G, Brauer A (2016) Multiple drivers of Holocene lake level changes at a lowland lake in northeastern Germany. Boreas 45:828-845

Enters D, Kirilova E, Lotter AF, Lücke A, Parplies J, Jahns S, Kuhn G, Zolitschka B (2010) Climate change and human impact at Sacrower See (NE Germany) during the past 13,000 years: a geochemical record. J Paleolimnol 43:719-737

Gałka M, Apolinarska K (2014) Climate change, vegetation development, and lake level fluctuations in Lake Purwin (NE Poland) during the last $8600 \mathrm{cal}$. BP based on a highresolution plant macrofossil record and stable isotope data $\left(\delta^{13} \mathrm{C}\right.$ and $\left.\delta^{18} \mathrm{O}\right)$. Quat Int 328:213-225

Gałka M, Miotk-Szpiganowicz G, Goslar T, Jęśko M, van der Knaap WO, Lamentowicz M (2013) Palaeohydrology, fires and vegetation succession in the southern Baltic during the last 7500 years reconstructed from a raised bog based on multi-proxy data. Palaeogeogr Palaeocl 370:209-221

Gałka M, Miotk-Szpiganowicz G, Marczewska M, Barabach J, van der Knaap WO, Lamentowicz M (2015) 
Palaeoenvironmental changes in Central Europe (NE Poland) during the last 6200 years reconstructed from a high-resolution multi-proxy peat archive. Holocene 25:421-434

Goslar T (1998) Late Glacial sediments of Lake Gościążchronological background. In: Ralska-Jasiewiczowa M, Goslar T, Madeyska T, Starkel L (eds) Lake Gościąż, Central Poland, A Monographic Study. Part I. W. Szafer Institute of Botany, Kraków, pp 119-124

Guyard H, Chapron E, St-Onge G, Anselmetti FS, Arnaud F, Magand O, Francus P, Mélières MA (2007) High-altitude varve records of abrupt environmental changes and mining activity over the last 4000 years in the Western French Alps (Lake Bramant, Grandes Rousses Massif). Quat Sci Rev 26:2644-2660

Haberzettl T, Fey M, Lücke A, Maidana N, Mayr C, Ohlendorf C, Schäbitz F, Schleser GH, Wille M, Zolitschka B (2005) Climatically induced lake level changes during the last two millennia as reflected in sediments of Laguna Potrok Aike, southern Patagonia (Santa Cruz, Argentina). J Paleolimnol 33:283-302

Hanebuth TJJ, Stattegger K, Bojanowski A (2009) Termination of the Last Glacial Maximum sea-level lowstand: the Sunda-Shelf data revisited. Global Planet Change 66:76-84

Jańczak J, Sziwa R (1995) Charakterysytka morfometrycznohydrologiczna jezior i zbiorników. In: Kaniecki A, Rotnicka J (eds) Wody Powierzchniowe Poznania. Sorus, Poznań, pp 344-355

Jouve G, Francus P, Lamoureux S, Provencher-Nolet L, Hahn A, Haberzettl T, Fortin D, Nuttin L, Team TP (2013) Microsedimentological characterization using image analysis and $\mu-\mathrm{XRF}$ as indicators of sedimentary processes and climate changes during Lateglacial at Laguna Potrok Aike, Santa Cruz, Argentina. Quat Sci Rev 71:191-204

Kaiser K, Lorenz S, Germer S, Juschus O, Küster M, Libra J, Bens O, Hüttl RF (2012) Late Quaternary evolution of rivers, lakes and peatlands in northeast Germany reflecting past climatic and human impact—an overview. E\&G Quat Sci J 61:103-132

Karczewski A (1976) Morphology and lithology of closed depression area located on the northern slope of Morasko Hill near Poznań. In: Hurnik H, Hurnik H (eds) Meteorite Morasko and region of its fall. Uniwersytet im. Adama Mickiewicza w Poznaniu, Poznań, pp 7-19

Kozarski S (1995) Deglacjacja północno-zachodniej Polski: warunki srodowiska i transformacja geosystemu (ok. 20 KA-10 KA BP). Continuo, Wrocław

Lamentowicz M, Obremska M, Mitchell EA (2008) Autogenic succession, land-use change, and climatic influences on the Holocene development of a kettle-hole mire in Northern Poland. Rev Palaeobot Palyno 151:21-40

Lamentowicz M, Gałka M, Obremska M, Kühl N, Lücke A, Jassey VEJ (2015) Reconstructing climate change and ombrotrophic bog development during the last 4000 years in northern Poland using biotic proxies, stable isotopes and trait-based approach. Palaeogeogr Palaeocl 418:261-277

Lauterbach S, Brauer A, Andersen N, Danielopol DL, Dulski P, Huels M, Milecka K, Namiotko T, Plessen B, von Grafenstein U, Participants D (2011) Multi-proxy evidence for early to mid-Holocene environmental and climatic changes in northeastern Poland. Boreas 40:57-72

Ljungqvist FC (2010) A new reconstruction of temperature variability in the extra-tropical Northern Hemisphere during the last two millennia. Geogr Ann A 92:339-351

Ljungqvist FC, Krusic PJ, Sundqvist HS, Zorita E, Brattström G, Frank D (2016) Northern Hemisphere hydroclimate variability over the past twelve centuries. Nature 532:94-98

Magny M (2004) Holocene climate variability as reflected by midEuropean lake-level fluctuations and its probable impact on prehistoric human settlements. Quat Int 113:65-79

Meyers PA, Ishiwatari R (1993) The early diagenesis of organic matter in lacustrine sediments. In: Engel M, Macko SA (eds) Organic geochemistry. Springer, New York, pp 185-209

Michczyńska DJ, Starkel L, Nalepka D, Pazdur A (2013) Hydrological changes after the last ice retreat in northern Poland using radiocarbon dating. Radiocarbon 55:1712-1723

Milecka K, Kowalewski G, Szeroczyńska K (2011) Climaterelated changes during the Late Glacial and early Holocene in northern Poland, as derived from the sediments of Lake Sierzywk. Hydrobiologia 676:187-202

Nowaczyk NR (2002) Logging of magnetic susceptibility. In: Last WM, Smol JP (eds) Tracking environmental change using lake sediments. Springer, Dordrecht, pp 155-170

Ohlendorf C, Fey M, Gebhardt C, Haberzettl T, Lücke A, Mayr C, Schäbitz F, Wille M, Zolitschka B (2013) Mechanisms of lake-level change at Laguna Potrok Aike (Argentina)insights from hydrological balance calculations. Quat Sci Rev 71:27-45

PAGES 2k Consortium (2013) Continental-scale temperature variability during the past two millennia. Nat Geosci 6:339-346

Pędziszewska A, Tylmann W, Witak M, Piotrowska N, Maciejewska E, Latałowa M (2015) Holocene environmental changes reflected by pollen, diatoms, and geochemistry of annually laminated sediments of Lake Suminko in the Kashubian Lake District (N Poland). Rev Palaeobot Palyno 216:55-75

Pompeani DP, Steinman BA, Abbott MB (2012) A sedimentary and geochemical record of water-level changes from Rantin Lake, Yukon, Canada. J Paleolimnol 48:147-158

Ralska-Jasiewiczowa M, Demske D, van Geel B (1998) Holocene regional vegetation history recorded in the Lake Gościąż sediments. In: Ralska-Jasiewiczowa M, Goslar T, Madeyska T, Starkel L (eds) Lake Gościąż, Central Poland. A monographic study. W. Szafer Institute of Botany, Polish Academy of Sciences, Kraków, pp 202-219

Reimer PJ, Bard E, Bayliss A, Beck JW, Blackwell PG, Ramsey CB, Buck CE, Cheng H, Edwards RL, Friedrich M, Grootes PM, Guilderson TP, Haflidason H, Hajdas I, Hatté C, Heaton TJ, Hoffmann DL, Hogg AG, Hughen KA, Kaiser KF, Kromer B, Manning SW, Niu M, Reimer RW, Richards DA, Scott EM, Southon JR, Staff RA, Turney CSM, van der Plicht J (2013) IntCal13 and Marine13 radiocarbon age calibration curves $0-50,000$ years cal BP. Radiocarbon 55:1869-1887

Schettler G, Rein B, Negendank JF (1999) Geochemical evidence for Holocene palaeodischarge variations in lacustrine records from the Westeifel Volcanic Field, Germany: 
Schalkenmehrener Maar and Meerfelder Maar. Holocene 9:381-400

Schnurrenberger D, Russell J, Kelts K (2003) Classification of lacustrine sediments based on sedimentary components. J Paleolimnol 29:141-154

Słowiński M, Marcisz K, Płóciennik M, Obremska M, Pawłowski D, Okupny D, Słowińska S, Borówka R, Kittel P, Forysiak J, Michczyńska DJ, Lamentowicz M (2016) Drought as a stress driver of ecological changes in peatland-a palaeoecological study of peatland development between 3500BCE and 200BCE in central Poland. Palaeogeogr Palaeocl 461:272-291

Snowball IF (1993) Geochemical control of magnetite dissolution in subarctic lake sediments and the implications for environmental magnetism. J Quat Sci 8:339-346

Stankowski W (2008) Meteoryt Morasko, osobliwość obszaru Poznania. Wydawnictwo Naukowe UAM, Poznań

Starkel L, Michczyńska D, Krąpiec M, Margielewski W, Nalepka D, Pazdur A (2013) Progress in the Holocene chrono-climatostratigraphy of Polish territory. Geochronometria 40:1-21

Steinhilber F, Beer J, Fröhlich C (2009) Total solar irradiance during the Holocene. Geophys Res Lett 36:L19704

Sternal B, Szczuciński W, Forwick M, Zajączkowski M, Lorenc S, Przytarska J (2014) Postglacial variability in near- bottom current speed on the continental shelf off southwest Spitsbergen. J Quat Sci 29:767-777

Szczucińska A (2016) Spring water chemistry in a formerly glaciated area of western Poland: the contribution of natural and anthropogenic factors. Environ Earth Sci 75:712

Szeląg-Wasielewska E (2004) Dynamics of autotrophic picoplankton communities in the epilimnion of a eutrophic lake (Strzeszynskie Lake, Poland). Ann Limnol Int J Lim 40:113-120

Wanner H, Solomina O, Grosjean M, Ritz SP, Jetel M (2011) Structure and origin of Holocene cold events. Quat Sci Rev 30:3109-3123

Weltje GJ, Tjallingii R (2008) Calibration of XRF core scanners for quantitative geochemical logging of sediment cores: theory and application. Earth Planet Sci Lett 274:423-438

Weltje GJ, Bloemsma MR, Tjallingii R, Heslop D, Röhl U, Croudace IW (2015) Prediction of geochemical composition from XRF core scanner data: a new multivariate approach including automatic selection of calibration samples and quantification of uncertainties. In: Croudace IW, Rothwell RG (eds) Micro-XRF studies of sediment cores. Springer, Berlin, pp 507-534

Woś A (1994) Klimat niziny wielkopolskiej. Wydawnictwo Naukowe UAM, Poznań 